\title{
FRUIT SET, FRUIT RETENTION AND YIELD OF CHILLI GENOTYPES UNDER HOT AND DRY CONDITION OF WESTERN TERAI OF NEPAL
}

\author{
K.C. Dahal', M.D. Sharma ${ }^{2}$ and R. Sapkota ${ }^{1}$ \\ ${ }^{1}$ Institute of Agriculture and Animal Sciences, Tribhuvan University, Nepal \\ ${ }^{2}$ Agriculture and Forestry Univesity, Nepal
}

\begin{abstract}
Thirteen selected chilli genotypes were evaluated in randomized completely block design with three replications to study the flowering, fruit set and yield potential during spring-summer of 2005 at Khajura, Banke (Western terai district of Nepal). High temperature, long drought period and hot wind blow during flowering and fruiting period severely affected the fruit set and fruit size. Only $18.81 \%$ flowers set fruits while $72.41 \%$ of set fruits reached to marketable size (harvesting). Wide variations observed in yield potential of the genotypes ranging total fruit number per plant from 6 to 71 and in total fruit yield 7.97 to $95.33 \mathrm{q} / \mathrm{ha}$. The genotype Mr. Lee No. 3 Selex produced maximum marketable fresh fruit yield $(90.69 \mathrm{q} / \mathrm{ha})$ which was $234.5 \%$ higher than that of Jwala (standard check) with $50.57 \%$ fruit set and $74.93 \%$ fruit retention. One fruit per plant was 0.63 and 0.52 coefficient of fruit set (\%) and fruit retention (\%) respectively. Highly significant coefficient of determination $\left(\mathrm{R}^{2}=0.86\right)$ of the product of fruit number per plant and 100 fruit weight $(\mathrm{g})$ against fresh fruit yield $(\mathrm{q} / \mathrm{ha}$ ) showed that chilli genotypes yield can be predicted considering fruit number per plant and fruit weight in hot and dry summer condition.
\end{abstract}

Key words: Pepper, capsicum, heat tolerant, flower drop and fruit drop

\section{INTRODUCTION}

Hot peppers or chilli (Capsicum spp.) of numerous shapes, sizes and pungency levels are indispensable condiment crop in Asian continents. Chillies are well adapted to warm climatic condition but vulnerable to extreme regime of temperatures. Frost free period with temperature range of 15-35 ${ }^{\circ} \mathrm{C}$ is optimum for better growth and development (Anand et al., 1992; Kraikraun, 1998; Deshpande, 2001; AVRDC, 2003). Abscission of flower buds, flowers and young fruits in pepper are the most important limiting factors (AVRDC, 1986). Extreme temperature is the principal environmental factor for abscission. (Cochran, 1936; Rylski and Spigelman, 1982; Olarewaju, 1989; Erickson and Markhart, 2001). Problems further compounded if the low relative humidity is accompanied with dry winds (Singh and Singh, 1991; Srinivasa Rao and Bhatta, 1993; Thakur et al., 2000).

Chillies are commonly grown in terai, inner terai, lower hills and mid hills of Nepal. Western terai regions are distinguished with relatively hot and dry climate than other parts of Nepal. Prevailing high temperature, blowing of hot wind and shortage of moisture during early summer and, high temperature and excessive moisture during rainy summer besides the susceptibility of viruses are the major factors limiting chilli cultivation (Sharma et al., 2004). Such conditions increase flower and fruit drop and reduce fruit size, fruit number resulting into reduced yield. Variation exists in ability to flowering, fruit set and yield of chilli cultivars (Wien et al., 1989; Rani, 1996; Gupta, 2003, Dahal et al. 2007), however their performance depends upon the interaction of environmental and genetic factors. Considering the fruit set and retention is one of the major characteristics for ultimate yield of chilli, cultivars need to be identified with desired characteristics for the year-round cultivation of chilli suitable for western terai of Nepal. 


\section{MATERIALS AND METHODS}

A Field experiment with thirteen selected chilli genotypes [Ten genotypes CCA-3331, CCA336B, CCA-984A, Mr. Lee No. 3 selex, PBC-142, Maor, CCA-119A, CCA-3288, Susan's Joy and CO-5678 introduced from AVRDC, Taiwan to Nepal and three commercial cultivars of Nepal Suryamukhi, NS-1701 and Jwala (standard check)] was conducted in randomized completely block design with three replications during spring-summer of 2005 in Banke, representing western terai of Nepal. The site is located at $20^{\circ} 06^{\prime}$ north latitude, $81^{\circ} 37^{\prime}$ ' east longitude and at an altitude of 180 masl. Twenty eight days old seedlings were planted at $50 \times 30 \mathrm{~cm}$ spacing in paired row basis plot of $1 \mathrm{~m}$ wide and 3.6 meter long as per the recommendation of International Chilli Pepper Nursery (ICPN) trials (Berke, 1999). Farmyard manure $3 \mathrm{~kg} / \mathrm{m}^{2}$, and a basal dose of 40:60:60 NPK kg/ha were applied through the combination of di-ammonium phosphate (DAP), urea and murate of potash before transplanting. In addition, two side dressing each with $40 \mathrm{~kg} \mathrm{~N} /$ ha were applied on 35 and 75 days after transplanting (DAT). The total number of plants in each plot was 24 . Two border plants of each row were excluded as border plants. Each plot was enclosed with small bunds for effective irrigation. All the inter-cultural operations like weeding and hoeing were carried out regularly at 15 days interval. Prophylactic sprays of Thiodion ${ }^{\circledR} 35$ EC ( $2 \mathrm{ml} /$ litre of water) were given at 15 days interval up to the flowering stage. Ten plants were randomly tagged with woolen thread during the earlier growth stage in each plot for identification and recording yield attributing characters afterwards.

During the peak fruiting stage, just-opened fifty flowers from five untagged (ten flowers from each) plants of each treatment were marked at the pedicel during $2^{\text {nd }}$ fortnight of May 2005. The total marked flowers were observed after 12 days of counting; either the marked fruits were dropped or set. The fruit set percentage was calculated by using this formula:

Fruit set $\%=\frac{\text { Number of set flowers }}{\text { Total no. of flowers marked }} \times 100$

Very young fruits were marked in five tagged plants at weekly interval from the fruiting stage till the 50 fruits attained to green maturity in each plot. Then, the total number of fruits harvested was summed up from the 50 marked fruits. Using the formula in percentage assessed fruit retention of each genotype as explained by Dahal (2005).

Fruit retention $(\%)=\frac{\text { Number of fruit harvested }}{50 \text { marked set fruit }} \times 100$

The mature green fruits were picked from ten tagged plants of each plot in each harvest. Fruits damaged from diseases, hot wind, sunscald or insects and severely shriveled were grouped as unmarketable whereas the fruits with acceptable appearance, color and free from defects were grouped as marketable. The number of marketable and nonmarketable fruits of each treatment of each picking was counted separately and summed up. Then the average marketable and nonmarketable fruit numbers per plant and yield $(\mathrm{q} / \mathrm{ha}$ ) were computed. The collected data were compiled and subjected to analysis by using the MS-excel program, graphics from sigmaplot 11.0 and multiple linear regressions from unscrambler (10.3). 


\section{Climate of the site and crop phenology}

\section{RESULTS AND DISCUSSION}

The weather parameters during the crop period showed that the experimental site experienced cold and foggy winters, and hot and dry summer. The winter temperature declined to $4{ }^{\circ} \mathrm{C}\left(27^{\text {th }} \mathrm{Jan}\right.$, 2005 ) while the maximum (max.) temperature reached up to $43.5^{\circ} \mathrm{C}$ during June, 2005. The average weekly max. and minimum (min.) temperatures were $30.89{ }^{\circ} \mathrm{C}$ and $16{ }^{\circ} \mathrm{C}$ respectively. Similarly, the average weekly relative humidity ranged from $45.67 \%$ ( $3^{\text {rd }}$ week of April, 2005) to $95.99 \%\left(2^{\text {nd }}\right.$ week of Jan, 2005). The average weekly max./min. temperatures exceed $32 / 15^{\circ} \mathrm{C}$ from $3^{\text {rd }}$ week of March to the end of the crop period with low relative humidity. The perusal of weather data indicates that the crop flowering and fruiting period coupled with high temperature and low humidity condition.

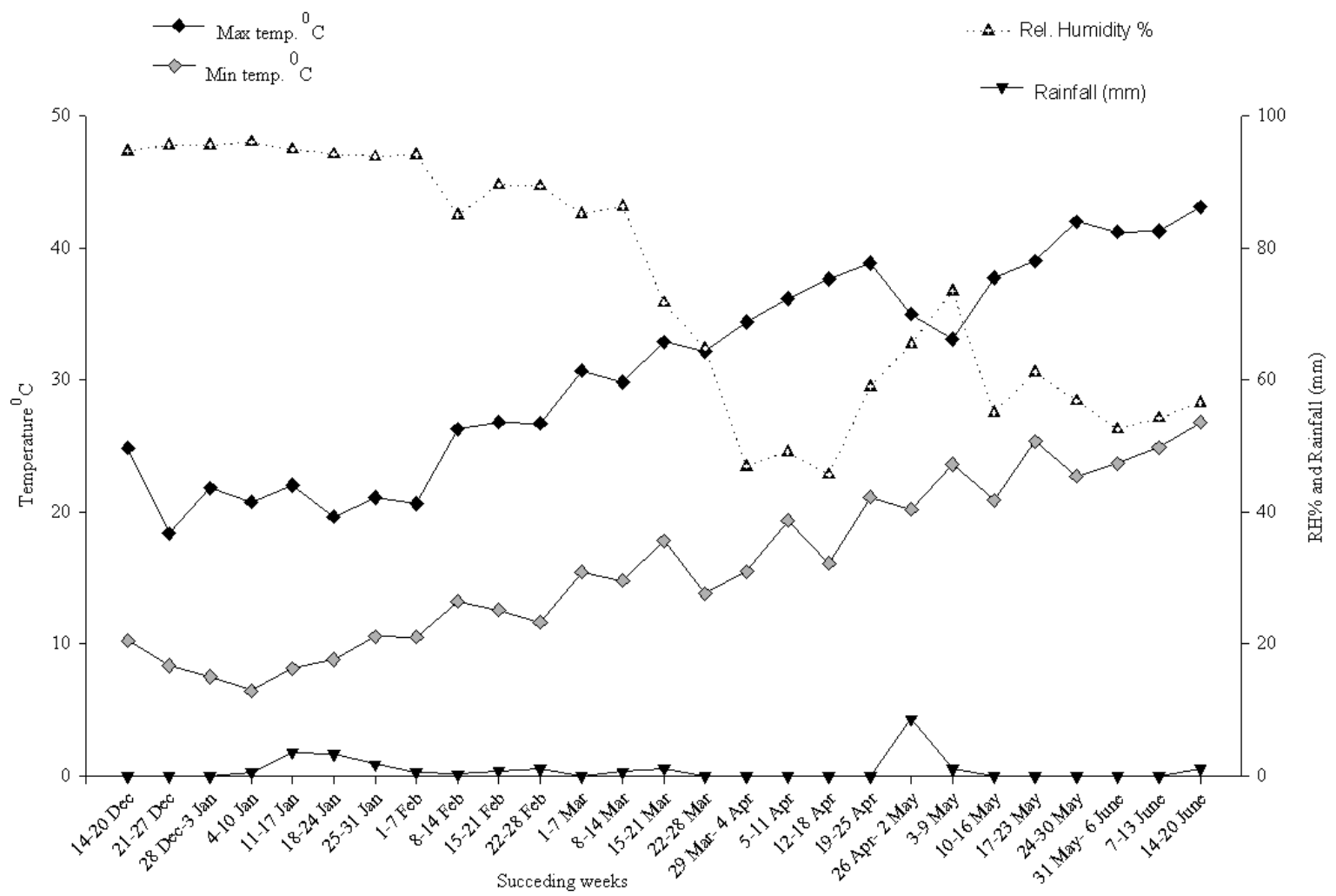

Figure 1. Meteorological data of experiment location during crop period at Khajura, Banke during 2004/2005

\section{Fruit set and fruit retention}

The data pertaining in Table 1 showed that highly significant variation was observed in fruit set percent while fruit retention percent did not differ significantly. The mean values of tested genotypes were $18.81 \%$ and $72.41 \%$ for fruit set and fruit retention percent, respectively. Significantly higher fruit set percent was observed in Suryamukhi and CO-5678 which was followed by the genotypes Mr. Lee No. 3 selex and CCA-119A. Whereas the other genotypes had lower fruit set percent than the average mean (18.81\%). Anand et al. (1992) found lower fruit set percent in chilli during summer with the average of $30.3 \%$ while in the main season it was $40.2 \%$. It was also observed that the fruit set percent was higher in the genotypes bearing flowers in upright position. Chaudhary (2004) also 
reported higher fruit set percentage in Suryamukhi (erect type) than in Jwala (pendent type). Among the tested genotypes, CO-5678 and Suryamukhi produce the flowers on the apical part of the main shoot that might be associated with better fruit set probably due to apical dominance of endogenous auxin which is necessary for better fruit set.

Table 1. Fruit set and fruit retention percent in chilli genotypes tested at Khajura, Banke, spring summer of 2005

\begin{tabular}{llll}
\hline \multirow{2}{*}{ S.N. } & Genotype & \multicolumn{2}{c}{ Percentage } \\
\cline { 3 - 4 } & & Fruit set & Fruit retention \\
\hline 1 & CCA-3331 & $9.33^{\mathrm{c}-\mathrm{e}}$ & 84.02 \\
3 & CCA-336B & $14.00^{\mathrm{c}-\mathrm{e}}$ & 64.80 \\
4 & CCA-984A & $10.68^{\mathrm{c}-\mathrm{e}}$ & 50.80 \\
5 & Mr. Lee No.3 selex & $31.28^{\mathrm{b}}$ & 81.41 \\
6 & MBC-142 & $15.02^{\mathrm{cd}}$ & 74.78 \\
7 & CCA-119A & $6.66^{\mathrm{e}}$ & 68.75 \\
8 & CCA -3288 & $26.28^{\mathrm{b}}$ & 72.66 \\
9 & Susan's Joy & $12.66^{\mathrm{c}-\mathrm{e}}$ & 66.72 \\
10 & CO-5678 & $7.33^{\mathrm{de}}$ & 71.37 \\
11 & Suryamukhi & $41.33^{\mathrm{a}}$ & 73.08 \\
12 & NS-1701 & $40.66^{\mathrm{a}}$ & 79.57 \\
13 & Jwala & $12.66^{\mathrm{c}-\mathrm{e}}$ & 71.59 \\
\hline LSD $(\mathrm{p}=0.05)$ & $16.66^{\mathrm{c}}$ & 81.87 \\
\hline Em \pm & & 7.25 & $\mathrm{n}$ \\
\hline
\end{tabular}

Values following different letters in a column are significant at $P=0.05$ by DMRT

Both short and long styled flowers were common in these genotypes. The additional reason of higher fruit set percent might be due to more convenient condition for pollination in the short styled flowers and promotion of self-pollination in the long styled flowers when passing the stigmas through the anther sacs in the erect flowers. Anand et al. (1992) reported that the frequency of stigma protrusion above the anthers was greater in small fruited chilli genotypes under high temperature condition. Rana and Kallo (1992) also observed variation in fruit set of tomato depending upon the flower bearing habit.

\section{Fruit set, retention and environment}

During intensive flowering and fruiting period weekly temperatures exceeding average weekly max./min. temperatures $32 / 15{ }^{\circ} \mathrm{C}$ prevented fruit set in some genotypes. Kraikraun (1998) 
observed no fruit set in hot pepper under prevailing high temperature $\left(37-40^{\circ} \mathrm{C}\right)$ whereas Erickson and Markhart (2001) noted that elevated temperature $\left(33^{\circ} \mathrm{C}\right)$ decreased fruit set but continued in flower production. In this study, when the average weekly max./min. temperature from $4^{\text {th }}$ week of the May, 2005 exceeded 39.01/24.76 $+2.05{ }^{\circ} \mathrm{C}$ then several genotypes could not bear even flowers. Hewitt and Curtis (1948) reported that increased respiration decrease carbohydrate level and prevent the flower production. It was also observed that the dropped fruits were either dried, sun scald or infected with common fruit rot diseases. Flower bud to mature fruit drops were common in most of the genotypes. It was frequently observed that drying of flower buds before anthesis was common in some genotypes particularly CCA-984A, CCA-336B, NS-1701and CCA-3288. Some genotypes such as CCA-3331, Susan's Joy, Maor, PBC-142, Jwala, CCA-119A and Mr. Lee No. 3 selex showed relatively more tolerance to bud drying while flower drop was common. Genotypes like CCA-984A and CCA-336B were observed with drying of unburst buds resulting into poor number of flowers when temperature increased above $32{ }^{\circ} \mathrm{C}$ which in-turn reduced fruit yield drastically.

\section{Fruit number and yield}

The data related to number of fruits and fruit yield per plant based on the aggregate of three pickings performed during the crop period varied significantly (data not presented). The mean values of total number of fruits of tested genotypes ranged from 5.61 in CCA-984A to 71 in Jwala. Similarly, number of marketable fruits per plant of tested genotypes ranged from 5.4 to 61.37. The number of marketable fruits per plant was highest in Mr. Lee No. 3 selex, however, it was statistically at par with those of CO-5678, CCA-3331 and Jwala. Mean values of total fruit yield showed that max fruit yield was harvested from the genotypes Mr. Lee No. 3 selex (90.69 q/ha) which was significantly higher than all other tested genotypes and it was $234.5 \%$ higher than the yield of Jwala $(27.11 \mathrm{q} / \mathrm{ha})$. Rani (1996) found that the heat tolerant genotypes yielded $48.01 \%$ more than Jwala.

Variations in fruit set (\%), fruit retention (\%), fruit number per plant, 100 fresh fruit weight ( $\mathrm{g}$ ) and fruit yield (q/ha) did not followed the same pattern. Multiple correlation coefficients revealed that the contribution of two factors namely percentage fruit set $\%$ and fruit retention $\%$ were highly significant with respective $\mathrm{p}$ value of 0.005 and 0.006 to explain the variation in fruit number per plant. Similarly, fruit number per plant $(p$ value $=0.000)$ and 100 fruit weight $(p$ value $=0.000)$ were highly significant to determine the variation in fruit yield. Per unit increment in fruit number was the product of 0.63 and 0.52 coefficients of fruit set and fruit retention per cent respectively that signifies fruit set had contributed more than fruit retention to explain the variation in fruit number per plant. Similarly, per unit variation in fruit yield $(\mathrm{q} / \mathrm{ha}$ ) was explained by the coefficient product of fruit weight and fruit number per vine. Linear correlation of fruit number per plant and 100 fruit weight with yield with correlation coefficient of 0.47 and 0.61 respectively showed positive correlation only however the interaction of these two parameters was strongly correlated $(r=0.92)$ with yield. Calibration and prediction results for fruit yield was determined largely by fruit number per plant and 100 fruit weight as described by high coefficient of determination of 0.86 as shown in Figure 2. 


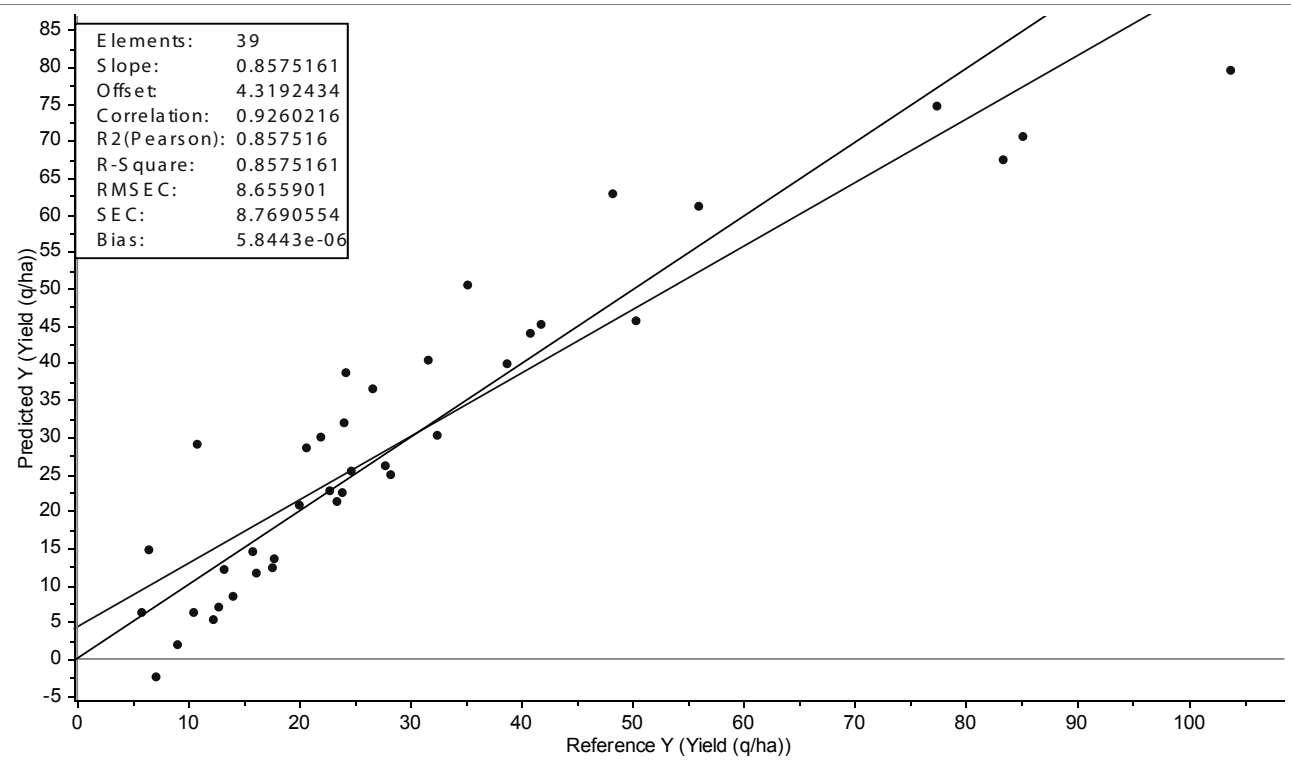

Figure 2. Multiple linear regression of predicted vs reference yield (q/ha) of 13 chilli genotypes considering the factors fruit number per plant and fruit weight (g)

In this study, the yield of all chilli genotypes was lower as compared to normal season crops. Summer season grown chilli fruits were shorter, narrower and lighter than those produced in the spring season and there was decline in the marketable and total yields by $65 \%$ and $63 \%$ respectively (AVRDC, 2003). Seasonal variations in the yield of chilli genotypes were also reported by Hundal and Khurana (1988); Uden (1998), Maur (1998), AVRDC (2002 and 2003) and Gupta (2003).

\section{CONCLUSION}

Higher fruit set was observed in upright flower bearing chilli genotypes than the pendent. However, the total fruit harvested per plant was not significantly dependent on fruit set and fruit retention. Flowering, fruit set and fruit retention in all tested chilli genotypes were greatly affected by the symptoms of bud drying, flower drop and fruit drop when daily max./min. temperature exceeded $39 / 24.7{ }^{\circ} \mathrm{C}$. It is concluded that the predicted yield can be achieved with the genotypes considering fruit number per plant and fruit weight rather than a single character in hot and dry summer condition of western Nepal.

\section{ACKNOWLEDGEMENTS}

We are also grateful to Dr. P. A. Gniffke, Pepper Breeder and Dr. I. M. Eagle, Head of the Plant Genetic Resources Unit, AVRDC, Taiwan for their help in the collection of elite germplasms as well as relevant information.

\section{REFERENCES CITED}

Anand, N., A. A. Deshpande and P. R. Ramchander. 1992. Differential response of bell pepper and chillies to high temperature stress. Veg. Sci. 19 (2):206-211.

Asian Vegetable Research and Development Centre (AVRDC). 1986. AVRDC adds pepper as new principal crop. Asian Vegetable Research and Development Centre, Center Point 5(1):1. 
Asian Vegetable Research and Development Centre (AVRDC). 2002. High yielding, disease-resistant chili peppers lines. In: AVRDC progress report-2002. AVRDC, Shanhua, Tainan, Taiwan. Pp. 18-21

Asian Vegetable Research and Development Centre (AVRDC). 2003. Development of high yielding, disease-resistant chilli peppers. In: AVRDC Progress report -2003. Asian Vegetable Research and Development Centre, Shanhua, Taiwan. pp. 41-46

Berke, T. G. 1999. Procedure for chili pepper field evaluation trials [Online]. Available: http://www. avrdc.org [Retrieved: Nov. 05, 2004).

Chaudhary, B. 2004. Response of chilli (Capsicum annuum L) to plant growth regulators. M. Sc. Ag. Thesis, Trivuwan University, Institute of Agriculture and Animal Sciences, Rampur, Chitwan, Nepal.

Cochran, H. L. 1936. Some factors influencing growth and fruit setting in the pepper (Capsicum frutescens L.). Cornell Agr. Expt. Sta. Memoir. 190 p.

Dahal, K.C. 2005. Evaluation of heat tolerant chilli (capsicum annuum L.) genotypes for spring summer in western terai of Nepal. M.Sc. Thesis (Unpublished) submitted to Institute of Agriculture and Animal Science, Tribhuvan University.

Dahal, K.C., M.D. Sharma, D.D. Dhakal and S.M. Shakya. 2007. Evaluatin of heat tolerant chilli genotypes. J. Inst. Agri. An. Sc., 27:58-61.

Deshpande, A. A. 2001. Chilli and capsicums (Capsicum annuum L.). In: S. Thanmburaj and N. Singh (eds.). Text Book of Vegetables, Tubercrops and Spices. ICAR, India. Pp. 49-51.

Ericson, A. N. and A. H. Markhart. 2001. Flower production, fruit set and physiology of bell pepper during elevated temperature and vapor pressure deficit. J. American Soc. Hort. Sci. 126(6):697702.

Gupta, M. K. 2003. Performance of chilli (Capsicum annuum L.) genotypes under tarai condition of uttranchal. Thesis, M. Sc. Ag., G. B. Pant University of Agriculture and Technology, Pantnagar, India. $123 \mathrm{p}$.

Hewitt, S. P. and C. F. Curtis. 1948. The effect of dry matter and carbohydrate from leaves by respiration and translocation. American J. Bot., 35:746-755.

Hundal, J. S. and D. S. Khurana. 1988. Heterosis potential on chillies. In: Proc. Natl. Seminar on Chillies, Ginger and Turmeric, Hyderabad, 11-12 Jan., 1988. Pp. 33-37.

Kraikraun, W. 1998. Effect of shading on the growth and yield of local hot pepper variety. In: AVRDC-ARC Research Report-1998. Asian Vegetable Research and Development Centre, Shanhuwa, Taiwan.

Maur, T. 1998. Long-fruited chilli evaluation trial. AVRDC-ARC research report 1998. Available: http://www.avrdc.org, [Retrieved: 1 Nov., 2004].

Olarewaju, J. D. 1989. Effects of night temperature on fruit set and developments in sweet pepper (Capsicum annuum L.). Haryana J. Hort. Sci. 18(3):285-288.

Rana, M. K. and G. Kallo. 1992. High temperature tolerance in tomato: evaluation of genotypes. Vegetable Science, 19(1): 71-78.

Rani, P. U.1996. Evaluation of chilli (Capsicum annuum L.) germplasm and its utility in breeding for higher yield and better quality. Maysore J. Agric. Sci. 30:343-348.

Rylski, I. and M. Spigelman. 1982. Effects of different diurnal temperature combinations on fruit set of sweet peppers. Scientia Hort. 17:101-106.

Sharma, M.D., R.B. Thapa, K.B. Adhikari and K.C. Dahal. 2004. A survey report on "Problems associated with poor fruit set and low yield in brinjal and chilli in mid and far western 
development regions of Nepal" submitted to National Agriculture Research and Development Fund. NARDF (PCN 041)/DOR IAAS, Rampur.

Singh, M. J. and J. Singh. 1991. Effect of cucumber mosaic virus on chlorophyll pigments in chillies (Capsicum annuum L.). Vegetable Science, 18(2):200-208.

Srinivasa Rao, N. K. and R. M. Bhatta. 1993. Physiological aspects of drought and heat tolerance in vegetables.In: K. L. Chadha and G. Kalloo (eds.) Advances in Horticulture- Vegetable crops 5 (I). Malhotra Publ. House, New Delhi, India. pp. 659-672.

Thakur, A., P. S. Thakur and S. P. Kandaujia. 2000. Effect of bioregulators, bioextracts and potassium on growth and related attributes in bell pepper (Capsicum annuum L.) varieties under water stress. Indian Journal of Agricultural Sciences, 70(8):255-258.

Uden, T. 1998. Hot pepper varietal trial (INTHROPE\#4). AVRDC-ARC research report-1998 [Online]. Available: http://www.avrdc.org, [Retrieved: 1 Nov. 2004].

Wien, H. C., K. E. Tripp, R. Hernandez-Armetana and A. D. Turner. 1989. Abscission of reproductive structures in pepper: causes, mechanisms and control. In: Tomato and Pepper Production in the Tropics. Proceedings of the International Symposium on Integrated Management Practices. Asian Vegetable Research and Development Centre, Shanhua, Taiwan. pp.150-165. 